\title{
OPERATING WIND GENERATOR WITH ALTERNATIVE RENEWABLE ENERGY SOURCES TO SUPPLY ISOLATED LOADS
}

\author{
A. A. El-Zeftawy* H.A. Yasin* and A. A. Gado** \\ * Dept of Elec. Engineering, Faculty of Engineering, Menoufiya University, Shebin El-kom, Egypt \\ ** Rural Electrification Authority, Ministry of Electricity \& Energy, Shebin El-kom, Egypt
}

\begin{abstract}
The energy output of a wind generator (WG) variable due to the variation of wind speed at the installation site through the day hours and year months. Therefore, a back-up power supply (BUPS) is necessary for operating WG to supply isolated loads. This BUPS may be diesel generator or/ and alternative sources of renewable energy system (RES) which are available at the installation site. The diesel generator as a BUPS with WG to supply isolated loads had been studied in previous publication.

In this work, alternative of RESs are studied and assessed as a BUPS for operating with WG to supply isolated loads. These alternatives are photovoltaic power system (PVPS) or/ and battery storage (BS). So, a hybrid model is presented here incorporates the added futures of dynamic modeling and graphic user interface in the power system block set and matlap program to assess the capacity of these BUPSs for operating with WG to supply isolated loads. Also, an economical model has been introduced to optimize the considered BUPSs from economical point of view. These models are applied numerically to estimate the capacity of alternative of WG/ BS and WG/ PVPS/ BS generation systems to supply an isolated load of a tourist village on the Egyptian coast of Red Sea. Also, these alternatives are optimized economically to supply the load study.

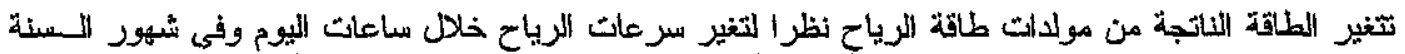

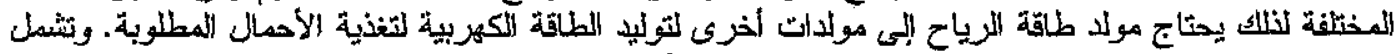

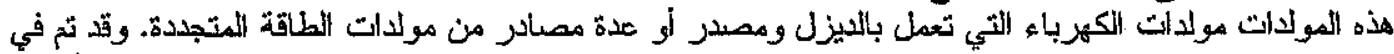

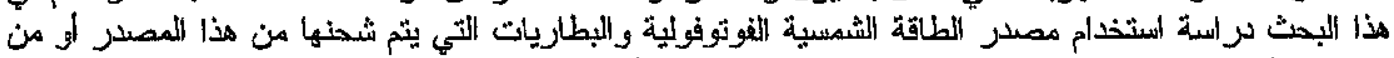

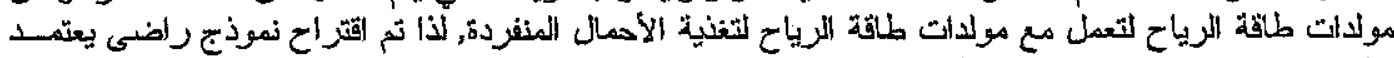

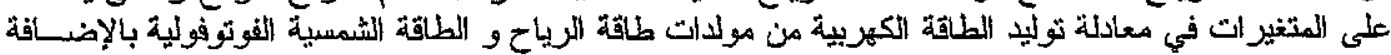

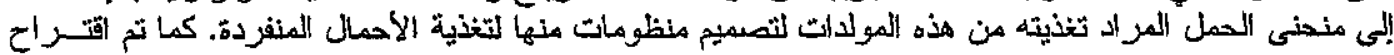

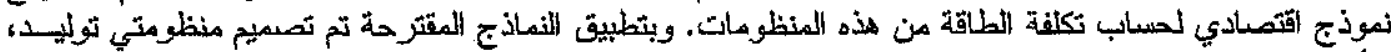

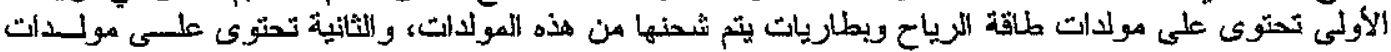

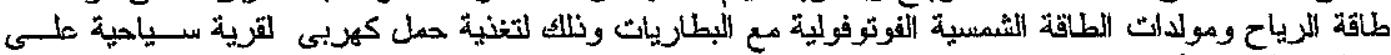

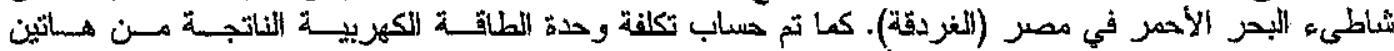

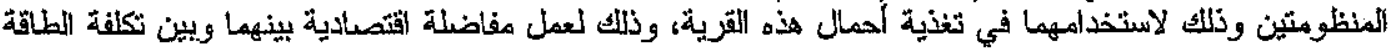

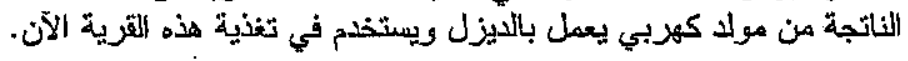

\section{INTRODUCTION}

Egypt is endowed by huge wind energy potentials where the coastal areas particularly the Red Sea Coast and the South Western parts of the country have high wind velocities reaching $10 \mathrm{~m} / \mathrm{s}$ and $7 \mathrm{~m} / \mathrm{s}$ respectively. Wind resources in coastal areas of Egypt have proven to be feasible both for mechanical pumping and electricity generation. Several organizations have directed efforts towards utilization of such resource $[2,3]$.

However, for small single village applications hybrid photovoltaic power systems (PVPSs) may play an economical role, particularly when used in combination with other technologies in a hybrid scheme and when adequate power storage is available. PVPS in hybrid systems can be the most cost-effective solution in some situations, such as when the costs of diesel fuel delivery increase fuel prices by $15-50 \%[4,5]$.

Correct sizing of remote area power system (RAPS) systems is very important, particularly if wind or solar energy is used. If the system is too small, power shortages will be experienced and the batteries may be damaged by excessive discharge. If the system is too large it will be unnecessarily expensive. The size of the system is dependent on the electrical load. The availability of wind and solar energy will also determine the size and type of 
system used. Suppliers of RAPS systems generally have methods of designing a system to meet each user's specific needs $[6,7]$.

In this work, hybrid system of wind generator, photovoltaic power system or/and battery storage has been designed and operated to supply isolated load at an site of Egypt using a suggested design model. Also, an economical model is presented to optimize different alternatives of this hybrid generation system.

\section{OPERATING WG WITH ALTERNATIVE RESs:}

Many of renewable energy sources (RESs) may be used with wind generators (WGs) as a backup power source (BUPS). The most convient types of these RESs are photovoltaic power system and storage batteries. So, alternative generation systems of WGs and these resources may be installed to supply isolated loads. These systems are:

Alternative I: Wind generator /BS generation system, Figure (1).

Alternative II: Wind generator / PVPS / BS generation system, Figure (2).

The WG generation curve can be used with the load curve at the study site to assess the capacity of BS and sizing the photovoltaic array for PVPS.

\section{Alternative I:}

In this case the battery charged from WG when; $P_{W G}(i)>P_{L}(i)$. Also, the capacity and charge / discharge cycle of BS are depending on both of wind generation and load curves.

To assess the capacity of these BUPS, the following load balance equation may be stated:

$$
\mathrm{P}_{\mathrm{WG}}(\mathrm{i}) \pm \mathrm{P}_{\mathrm{B}}(\mathrm{i})=\mathrm{P}_{\mathrm{L}}(\mathrm{i})
$$

Where; $\mathrm{P}_{\mathrm{wG}}(\mathrm{i}), \mathrm{P}_{\mathrm{B}}(\mathrm{i})$ are the hourly power supplied by $W G$ and $B S$, and $P_{L}(i)$ is the hourly load demand.

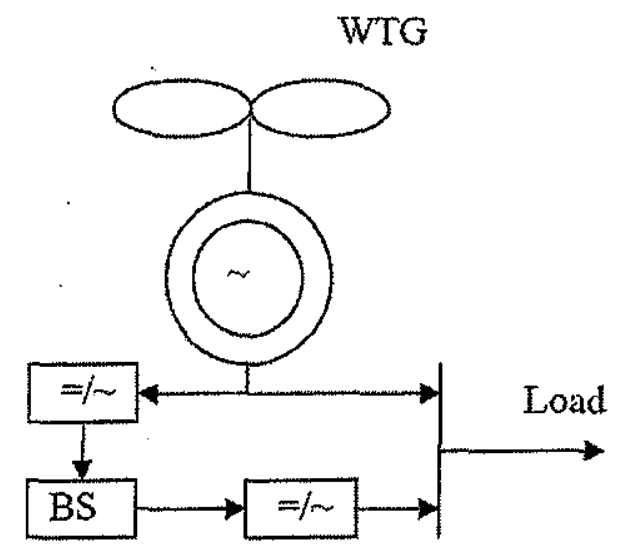

Fig (1) Line diagram of WG/BS generation system.
Hence, the energy supplied to the load by this battery $\left(\mathrm{E}_{\mathrm{BS}}\right)$ is:

$\mathrm{E}_{\mathrm{BS}}=\mathrm{E}_{\mathrm{GW}}-\mathrm{E}_{\mathrm{L}}$

Where, $E_{W G}$ and $E_{L}$ are the output energy of WG and energy requirement for the load respectively. At the ve sign of $E_{\mathrm{BS}}$, the $B S$ is in discharge case and +ve sign it is charged.

The capacity of BS in this case is given as a function of overall efficiency of BS ( $\left.\eta_{\mathrm{BS}}\right)$ and consists of long-term BS capacity (LTBS) and shortterm BS capacity (STBS). These capacities are developed as following:

$$
\begin{aligned}
& \text { STBS }=\mathrm{E}_{\text {def }}(\mathrm{m})_{\max } /\left[\mathrm{N}_{c d}(\mathrm{~m})^{*} \eta_{B S}\right] \\
& \text { LTBS }=\left[\sum^{\mathrm{m}} \mathrm{E}_{\text {def }}(\mathrm{m}) / \eta_{\mathrm{BS}}\right]-\mathrm{STBS}
\end{aligned}
$$

$\mathrm{BS}=\mathrm{STBS}+\mathrm{LTBS}$

Where:

$E_{\text {def }}(m)=E_{W G}(m)-E_{L}(m)$ at $E_{L}(m)>E_{W G}(m)$, and

$E_{W G}(m)_{\max }, E_{W G}(m)_{\min }$ : the monthly maximum and minimum output of WG

$\left[E_{W G}(m)-E_{L}(m)\right]_{\max }$ : the maximum difference between WG output and load demand through the month $m$ of the year $\left(\mathrm{E}_{\mathrm{der}}(\mathrm{m})_{\max }\right)$.

$\mathrm{N}_{\mathrm{cd}}(\mathrm{m})$; the number of charge-discharge cycles through the month $\mathrm{m}$.

The unit energy cost $\left(\mathrm{UEC}_{1}\right)$ of WG/ BS generation system may be developed as a function of economy of WG and BS. These economies are developed as followings:

The annual capital cost $\left(\mathrm{ACC}_{1}\right)$ of this system is:

$\mathrm{ACC}_{1}=\mathrm{ACC}_{\mathrm{WG}}+\mathrm{ACC}_{\mathrm{BS}}$

Where; $\mathrm{ACC}_{\mathrm{WG}}=\mathrm{DR}_{\mathrm{WG}} * \mathrm{C}_{\mathrm{WG}} * \mathrm{P}_{\mathrm{WG}}$

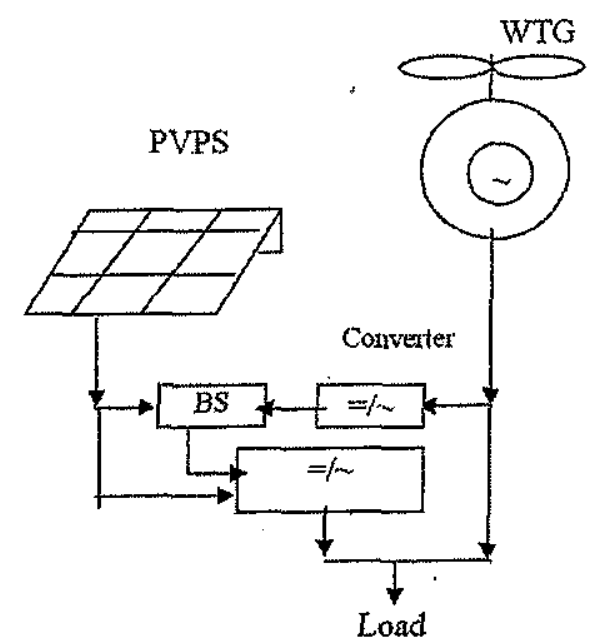

Fig (2) Line diagram of WG /PVPS/BS generation system. 


$$
\mathrm{ACC}_{\mathrm{BS}}=\mathrm{DR}_{\mathrm{b}} * \mathrm{C}_{\mathrm{b}} * \mathrm{CB}
$$

, and $P_{W G}$ is the rated power of WG, CB is the capacity of $B S, C_{W G}$ is the capital cost of $1 \mathrm{~kW}$ of $P_{W G}, C_{B}$ is the capital cost of $1 \mathrm{kWh}$ of $B S$, and DR is the annual discount rate which is depend on the interest rate ( $r$ ) and life time(n) of both of WG and $\mathrm{SB}$. This DR is given by [8]:

$\mathrm{DR}=\mathrm{r}(1+\mathrm{r})^{\mathrm{n}} /\left[(1+\mathrm{r})^{\mathrm{n}}-1\right]$

The annual operation cost $\left(\mathrm{AOC}_{1}\right)$ of WG/BS system is stated as:

$$
\begin{aligned}
& \mathrm{AOC}_{1}=\mathrm{AOC}_{\mathrm{WG}}+\mathrm{AOC}_{\mathrm{BS}} \\
& \text { Where; } \mathrm{AOC}_{\mathrm{WG}}=\mathrm{b}_{\mathrm{W}} \mathrm{E}_{\mathrm{WG}} \\
& \mathrm{AOC}_{\mathrm{BS}}=\mathrm{m}^{*} \mathrm{ACC}_{\mathrm{BS}}
\end{aligned}
$$

Where; $b_{w}$ is the operation cost per $1 \mathrm{kWh}$ of $E_{\mathrm{wg}}$, and $m$ is a percentage of capital cost of storage battery. Thus, the total annual cost $\left(\mathrm{TAC}_{1}\right)$ and $\mathrm{UEC}_{1}$ of this system are:

$$
\begin{aligned}
& \mathrm{TAC}_{1}=\mathrm{ACC}_{1}+\mathrm{AOC}_{1} \\
& \mathrm{UEC}_{1}=\mathrm{TAC}_{1} / \mathrm{E}_{\mathrm{L}}
\end{aligned}
$$

Where;

$$
\mathrm{E}_{\mathrm{L}}=\sum_{\mathrm{i}=1}^{8760} \mathrm{P}_{\mathrm{L}}(\mathrm{i})
$$

Alternative II : At deficit generation of WG through the sunshine periods, the load is supplied from a PVPS in this case. While the battery storage is charged by either of WG or/and PVPS. So, Eqn. (1) is modified as:

$$
\mathrm{P}_{\mathrm{WG}}(\mathrm{i})+\mathrm{P}_{\mathrm{pv}}(\mathrm{i})+\mathrm{P}_{\mathrm{bs}}(\mathrm{i})=\mathrm{P}_{\mathrm{L}}(\mathrm{i})
$$

Also, the annual energy supplied of PVPS $\left(E_{p v}(a)\right)$ is developed as a function of the annual electric generation of WG and load demand during the sunshine periods as :

$$
E_{p v}(a)=\sum^{t_{1}} P_{L}^{\prime}(i)-P_{W G}^{\prime}(i)
$$

Where:

$$
\mathrm{E}_{\mathrm{pv}}(\mathrm{a})=\mathrm{E}_{\mathrm{pv}(\mathrm{d})}(\mathrm{a})+\mathrm{E}_{\mathrm{pv}(\mathrm{s})}(\mathrm{a})
$$

, and $E_{\mathrm{pv}(d)}(\mathrm{a})$ and $E_{\mathrm{pv}(\mathrm{s})}(\mathrm{a})$ are the annual energy supplied directly to the load and from BS charged by PVPS. $P_{L}^{\prime}(i)$ and $P_{w G}^{\prime}(i)$ are the hourly load demand and wind generation through the annual sunshine hours $t_{\mathrm{s}}$.

The array size of PVPS to generate $E_{p v}(a)$ is developed from the deficit generation of WG to satisfy the energy requirement through the sunshine periods of the year months, monthly solat radiation received on this array, $\mathrm{H}_{\mathrm{t}}(\mathrm{m})$, at the installation site and the efficiencies of PV array $\left(\eta_{c}\right)$ and power conditioner $\left(\eta_{\mathrm{pc}}\right)$. The monthly $\mathrm{S}_{\mathrm{v}}(\mathrm{m})$ is given as:

$$
S_{v}(m)=\left[E_{L}(m)-E_{w O}(m)\right] / H_{t}(m) * \eta_{c}^{*} \eta_{\infty}
$$

, and the global PV array size $\left(\mathrm{S}_{\mathrm{pv}}\right)$ is:

$$
\mathrm{S}_{\mathrm{pv}}=\sum^{\mathrm{m}} \mathrm{S}_{\mathrm{pv}}(\mathrm{m}) / \mathrm{N}_{\mathrm{m}}
$$

Where $\left[E_{L}(m)-E_{W G}(m)\right]_{s p}$ is the difference between $E_{L}$ and $E_{W G}$ through the sunshine periods of the month $\mathrm{m}$ and $\mathrm{N}_{\mathrm{m}}$ is the number of the months have this difference.

Corresponding to $\mathrm{S}_{\mathrm{PV}}$, the monthly generation of PVPS, $E_{p v}(m)$, is given by:

$\mathrm{E}_{\mathrm{pv}}(\mathrm{m})=\mathrm{S}_{\mathrm{pv}} * \mathrm{H}_{\mathrm{t}}(\mathrm{m}) * \eta_{\mathrm{c}} * \eta_{\mathrm{pc}}$

The LTBS and STBS are developed in this case as following:

$$
\begin{aligned}
& \text { STBS }=\left[\mathrm{E}_{\mathrm{wo}}(\mathrm{m})+\mathrm{E}_{\mathrm{pp}}(\mathrm{m})-\mathrm{E}_{\mathrm{L}}(\mathrm{m})\right]_{\max } /\left[\mathrm{N}_{\mathrm{oc}}(\mathrm{m})^{*} \eta_{\mathrm{BB}}\right] \\
& \text { LTBS }=\sum^{\mathrm{m}}\left\{\left[\mathrm{E}_{\mathrm{wG}}(\mathrm{m})+\mathrm{E}_{\mathrm{pv}}(\mathrm{m})\right]_{\max }-\mathrm{E}_{\mathrm{L}}(\mathrm{m})_{\mathrm{min}}\right\} / \eta_{\mathrm{bs}}
\end{aligned}
$$

To assess the unit energy cost $\left(\mathrm{UEC}_{2}\right)$ of this system, the economy of WG, PVPS and BS are determined. This economy is developed in terms of ACC, AOC and TAC. These costs are determined for WG and BS as in alternative I. While these costs are evaluated for PVPS as following:

1. Chosen the PV module used, the number of PV modules, $N(m)$, and peak power of PVPS, $P_{p v}$, are given as:

$$
\begin{aligned}
& N(m)=S_{p v} / S_{p v}(m) \\
& P_{p v}=N(m) * P_{p v}(m)
\end{aligned}
$$

Where, $S_{p v(m)}$ and $P_{p v(m)}$ are the net area and peak power of the $P V$ module respectively.

2. The ACC, AOC and TAC of PVPS are given by:

$$
\begin{aligned}
& \mathrm{ACC}_{\mathrm{pv}}=\mathrm{DR}_{\mathrm{v}} * \mathrm{C}_{\mathrm{pv}} * \mathrm{P}_{\mathrm{pv}} \\
& \mathrm{AOC}_{\mathrm{pv}}=\mathrm{C}_{\mathrm{opv}} * \mathrm{E}_{\mathrm{pv}}(\mathrm{a}) \\
& \mathrm{TAC}_{\mathrm{pv}}=\mathrm{ACC}_{\mathrm{pv}}+\mathrm{AOC}_{\mathrm{pv}}
\end{aligned}
$$

Where; $C_{p v}$ and $C_{o p v}$ are the capital cost of $1 \mathrm{~kW}$ of Ppv and operation cost per $1 \mathrm{kWh}$ of the annual energy supplied by PVPS, Epv(a), respectively. Thus, the total annual cost (TAC2) and unit energy cost (UEC2) of WG /BS /PVPS generation system are:

$$
\begin{aligned}
& \mathrm{TAC}_{2}=\mathrm{TAC}_{\mathrm{WG}}+\mathrm{TAC}_{\mathrm{BS}}+\mathrm{TAC}_{\mathrm{pv}} \\
& \mathrm{UEC}_{2}=\mathrm{TAC}_{2} / \mathrm{E}_{\mathrm{L}} \text { (a) }
\end{aligned}
$$

$\mathrm{UEC}_{1}$ and $\mathrm{UEC}_{2}$ are compared to define the optimal BUPS of RES study may be used with WG to supply the isolated load at the considered site.

\section{OPTIMIZING ALTERNATIVE RESS WITH WG TO SUPPLY THE ISOLATED LOAD STUDY:}

The proposed generation and cost models, section 2, are applied here using Matlab program (MLP) to optimize different WGMs and alternative RESs used to supply an isolated load of a tourist 
village on the Egyptian coast of Red Sea (Hurghada). These WGMs have a rated of 100, 300 and $600 \mathrm{~kW}$. The average daily load curve of this tourist village is shown in Figure (3). This Figure gives the average hourly load demand through a day of Winter and summer seasons. Using the methodology of Ref. [9] the hourly generation curve of different WGMs are determined and shown in Figure (4) for a day of Winter and Summer seasons at Hurghada site.

\subsection{Assessement of Alternative I; WG/BS} Generation System:

Using the MLP, The results of Figure (4) are compared with load demand, Figure (3), and resultant in the number of different WGMs and BS capacity required for Alternative I (WG/BS generation system) to supply the study load and given in Table (1). Also, the economy of these hybride generation systems are obtained in terms of unit energy cost at using the following economical assumption. [5,10]

- The capital cost of WG and BS are $\$ 700 / \mathrm{kW}_{\mathrm{r}}$ and $\$ 40 / \mathrm{kWh}$ of $C B$ respectively.

- The operation cost of WG is $1.0 \phi / \mathrm{kWh}$ of $\mathrm{E}_{\mathrm{WG}}$. This cost is $5 \%$ of BS capital cost.

- The life time of WG and BS are 15 and 5 years respectively, while the interest rate for both is 10 $\%$. Thus, UEC $_{1}$ is obtained and given in Table (1). The result of this table conciuded that the WGM of $600 \mathrm{~kW}$ rate is the most economical one of these hybrid generation systems for isolated load study.

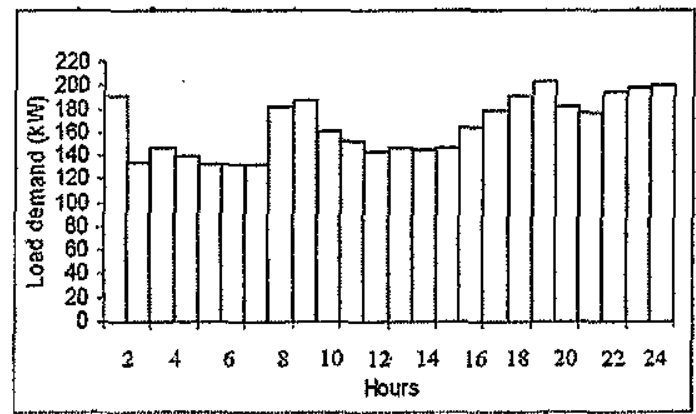

a) Winter season

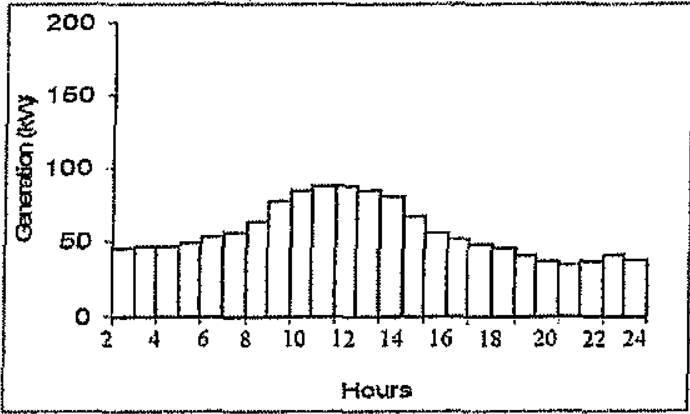

b) Summer season

Fig (3) The daily load demand for the tourist village study through a dav of different vear seasons

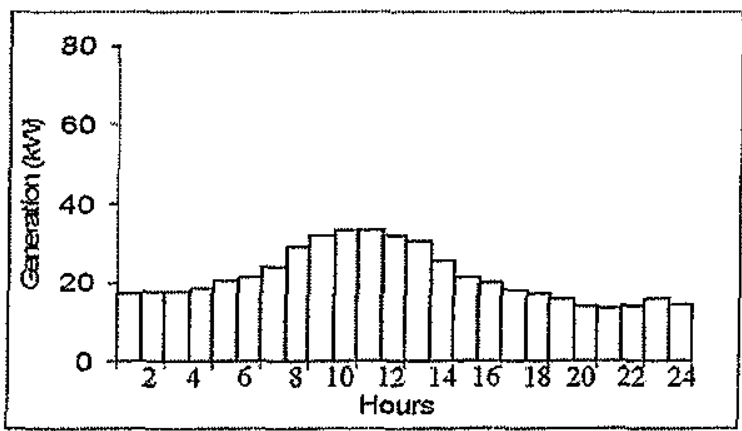

a- Winter season

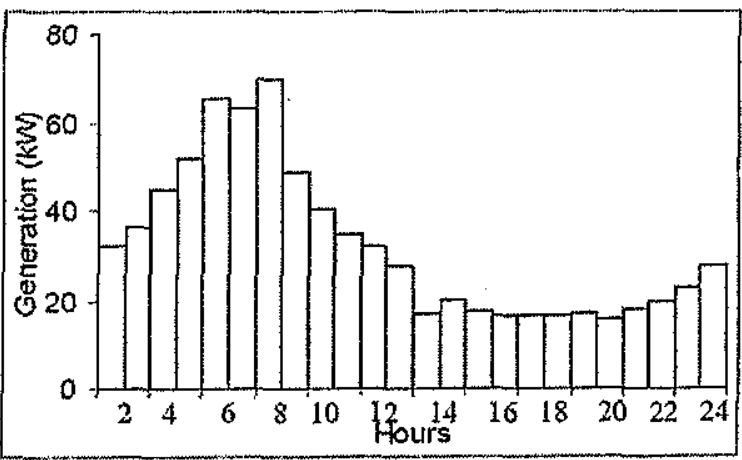

b-Summer season.

a) $100 \mathrm{~kW}$

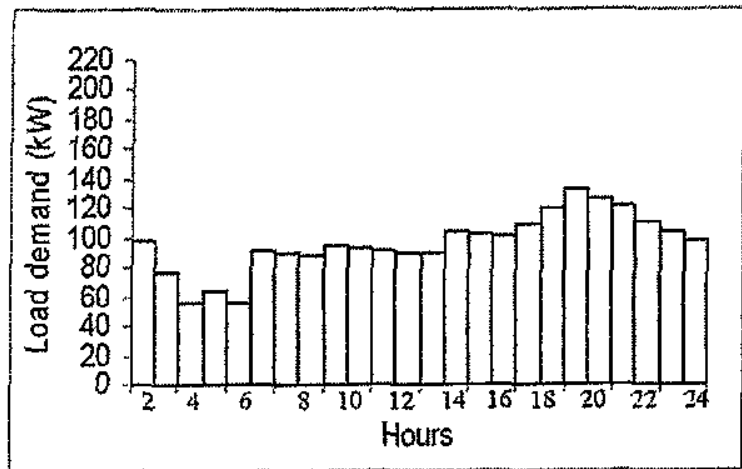

a) Winter season

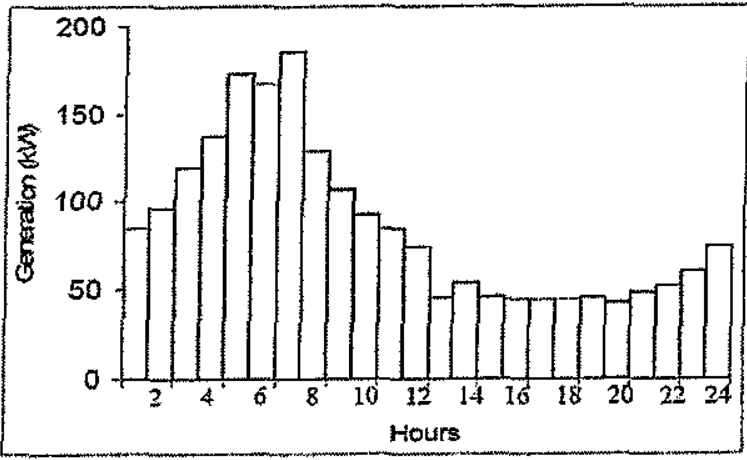

b- Summer season. b) $300 \mathrm{KW}$ 


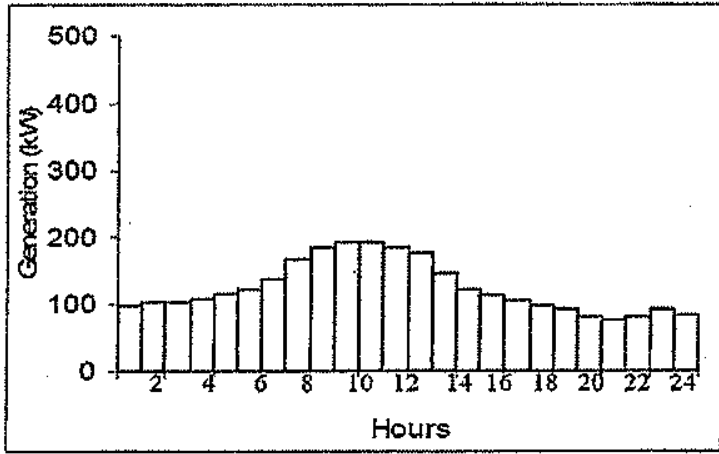

a- Winter season

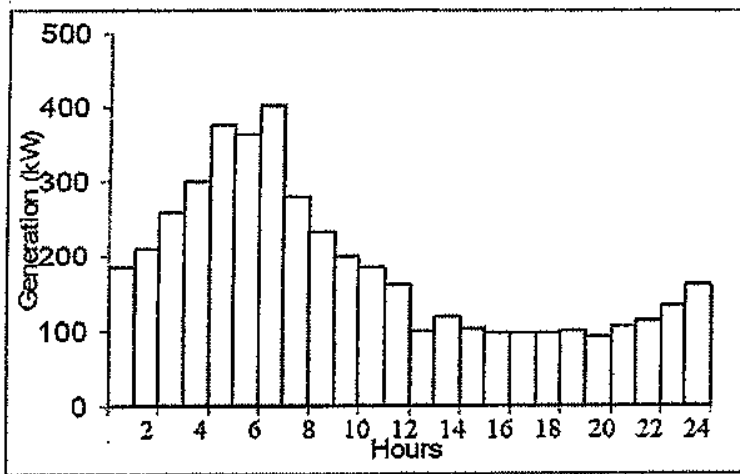

b- Summer season.

Fig (4) The average daily generation of different WGMs at Hurghada through the year seasons.

Table (1).The number of different WGMs and the corresponding BS capacity for Alternative I (WG/BS) generation system to supply the isolated load study

\begin{tabular}{|c|c|c|c|}
\hline WGM & $\begin{array}{c}\text { Number of } \\
\text { WG }\end{array}$ & $\begin{array}{c}\text { BS capacity } \\
(\mathrm{MWh})\end{array}$ & $\begin{array}{c}\text { Unit energy cost } \\
(\phi / \mathrm{kWh})\end{array}$ \\
\hline $100 \mathrm{~kW}$ & 7 & 178 & 167.5 \\
\hline $300 \mathrm{~kW}$ & 3 & 144 & 136.7 \\
\hline $600 \mathrm{~kW}$ & 2 & 34 & 37.5 \\
\hline
\end{tabular}

\subsection{Assessment of Alternative II; WG/PV/BS} Generation System:

The MLP is applied here using the proposed model of alternative II, section 2, with the results of Figures (3) and (4) to optimize the number of each WGM study in terms of the deficit generation through the sunshine periods of different year months. These deficits are used with the montbly solar radiation at Hurghada site [11] and the design model of Ref [12] to estimate the monthly and global PV array sizes to meet the deficit generation of WGMs through the sunshine periods. Solar radiation received on PV array is developed using the proposed model in Ref [13] and shown in Figure (5).Also, the global PV array size is used with monthly solar radiation at the study site to determine the monthly generation of PVPS to meet the deficit generation of WGMs or land charge the BS, Figure (2). The results of this application are summarized in Table (2). This table illustrates the optimal number of the WGMs study, the corresponding PV size and BS capacity. Also, the unit energy cost of different hybride generations of Alternative II is determined and shown in Table (2). Taking the following assumptions into consideration $[5,10]$ :

- The capital cost of PVPS is $5 \$ / \mathrm{W}_{\mathrm{p}}$ and operation cost is $0.2 \phi / \mathrm{kWh}$ of $\mathrm{E}_{\mathrm{PV}}$.

- The life time of PVPS is 20 years and interest rate is $10 \%$

The results of this application are obtained in terms of $\mathrm{UEC}_{2}$ and given in Table (2). The results of this table concluded that $300 \mathrm{~kW}-W \mathrm{WM}$ is the most economical ones for Alternative II (WG/BS/PVPS generation system).

Table (2).The number of different WGMs and the corresponding PVPS size and BS capacity for Alternative II (WG/BS/PVPS generation system). to supply the isolated load study.

\begin{tabular}{|c|c|c|c|c|c|}
\hline \multirow{2}{*}{$\begin{array}{c}\text { WGM, } \\
\mathrm{kW}\end{array}$} & \multirow[b]{2}{*}{$\begin{array}{l}\text { Number } \\
\text { of WG }\end{array}$} & \multicolumn{2}{|c|}{ PVPS size } & \multirow{2}{*}{$\begin{array}{c}\mathrm{BS} \\
\text { capacity } \\
(\mathrm{MWh})\end{array}$} & \multirow{2}{*}{$\begin{array}{c}\text { UEC } \\
(\phi / k W h)\end{array}$} \\
\hline & & $\mathrm{S}_{\mathrm{v}}, \mathrm{m}^{2}$ & $\begin{array}{c}\mathrm{P}_{\mathrm{v}} \\
\mathrm{kW}_{\mathrm{P}} \\
\mathrm{kWh}\end{array}$ & & \\
\hline 100 & 7 & 79 & 17.942 & 76 & 74.5 \\
\hline 300 & 3 & 190 & 39.514 & 0.0338 & 36.8 \\
\hline 600 & 2 & - & - & 34 & 37.5 \\
\hline
\end{tabular}
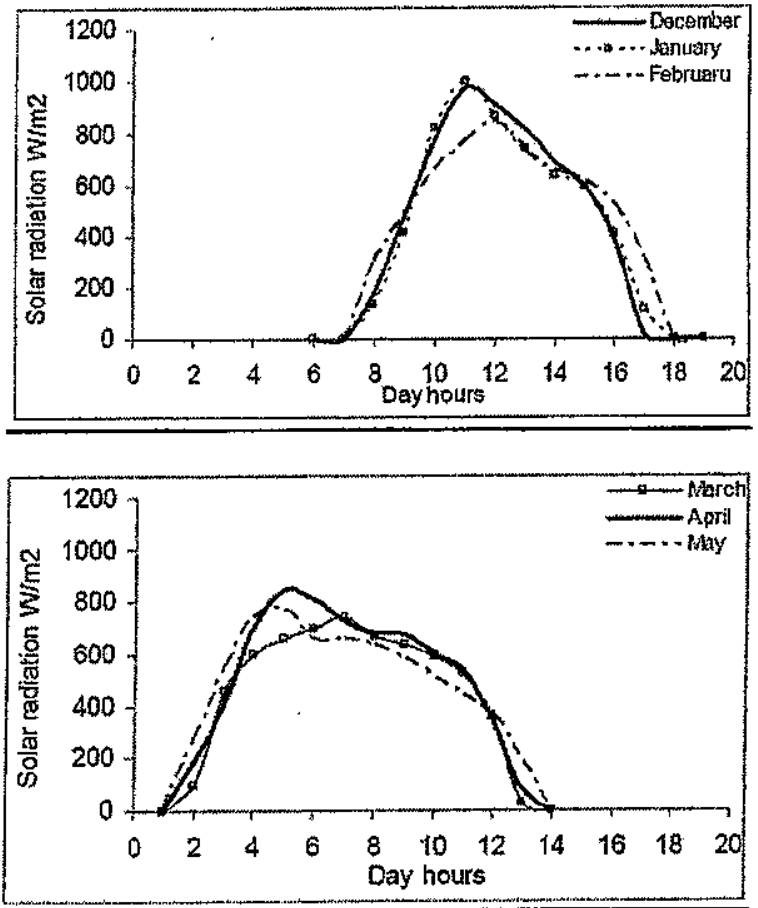

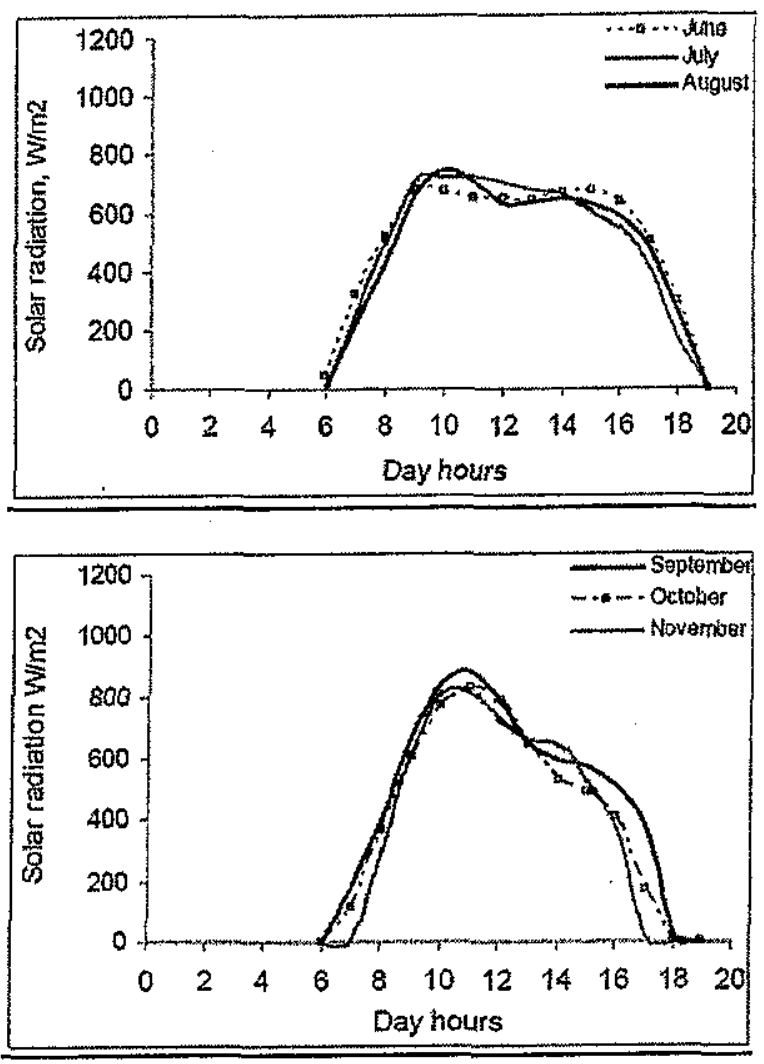

Fig (5) The hourly solar radiation received on unit area of PVPS through a day of the year months at Hurghada site.

\section{CONCLUSIONS:}

A hybrid generation and economical models are presented for operating alternative of renewable energy sources as a back-up- power supply with wind generator to supply isolated loads. These models are applied to assess and optimize the generation of hybrid generation systems of WG/ BS and WG/ PVPS/ BS have alternative of WGMs to supply the load of a tourist village on the Egyptian coast of Red Sea. The remarkable results of this application are:

1- For WG/ BS generation system; two wind generators of $600 \mathrm{~kW}$ rate with $34 \mathrm{MWh}$ BS capacity is the optimal hybrid generation system in this case (UEC $=37.5 \phi / \mathrm{kWh}$ ) at Hurghada site.

2- For WG/ PVPS/ BS generation system, three wind generators of $300 \mathrm{~kW}$ rate, PVPS have an array of $190 \mathrm{~m}^{2}$ and $33.8 \mathrm{kWh}$ BS capacity is the optimal hybrid generation system in this case (UEC $=36.8 \phi / \mathrm{kWh}$ )

\section{REFRENCES:}

[1] A.B.Mayhoub and A.Azzam; "A Survey on the Assessment of Wind Energy Potential in Egypt" Renewable Energy, vol.11, No.2, 1997, pp. 235247.

[2] M.S. Zannoun, New \& Renewable Energy Authority (NREA), Egypt;" Egypt's Renewablr Energy Strategy, Achievements and Programs" World Energy Council 18 the_Congress, Buenos Aires, October 2001.

[3] Schmid and Hoffmann; "Photovoltaic, Wind and Other Disperesed Energy Sources" Ref. 317.htm.

[4] El-Tamally, H.H. and Rakha, H.H.;"Design and Performance of Electrical WTG/BS/DG Power Generation System with its Application in Egypt" MEPCON'2003, Shebin El-Kom, Egypt, December16-18 2003, pp.835-843.

[5] Victorian Solar Energy Council; "Rural and Remote Area Power Supplies for Australia" Report prepared by the Department of Primary Industries and Energy, 2001.

[6] Wind Feature, Html "Wind Energy Progxam "www. eere. Energy. gov, 2003.

[7] Carl Brothers;" Cost Analysis "Atlantic Wind Test Site Inc., February 2002.

[8] Aly, GEM, EL-Gharbawy, A.E. and ELZeftawy,A.A.;" Integrated Wind Generator with conventional power system on Electric utility" Proceedings of Second World Conference on Technology Advances for Sustainable Development, Cairo, Egypt, March 2002, pp. 1114.

[9] "Economics of Wind Energy Prospects and Directions" First Published in Renewable Energy World, James\& James Science Publishers 1td, July-August, 2001.

[10] Meteorological Authority of Egypt, Personal Communication.

[11] Aly, GEM, EL-Zeftawy, A.A., Eraqy, S.A- and Abo- El-Azem, A.M.;" Modeling of Alternative PV System Design Methods and Application in Egypt" Proceedings of MEPCON' 2003, Shebin El-kom, Egypt, December 16-18,2003, PP. 671675.

[12] El.Zeftawy, A.A, El-Hefnawy, A.A, Aly, G.E.M. and Eraky, S.A.;" Solar Radiation Analysis and Modelling" proceedings of 7 Intermational Conference on Energy and Environment, Cairo, March 11-18, 2000, pp. 253-263 